\title{
Canadian and international recommendations on the frequency of HIV screening and testing: A systematic review
}

\author{
Austin $\mathrm{T}^{1}$, Traversy $\mathrm{GP}^{1}$, Ha S $\mathrm{S}^{1}$, Timmerman $\mathrm{K}^{1^{*}}$
}

\begin{abstract}
Background: In 2014, the Public Health Agency of Canada estimated that $21 \%$ of the people living with human immunodeficiency virus (HIV) in Canada were unaware of their infection. Increased screening and testing for HIV is crucial to reducing the number of undiagnosed infections. To ensure the best use of available resources, it is important to determine the optimal intervals for HIV screening and testing.
\end{abstract}

Objective: To conduct a systematic review of the recommendations for the frequency of HIV screening and testing in different populations.

Methods: To identify eligible guidelines, a comprehensive two-tiered search strategy of journals and websites of governments and non-governmental organizations and a three-tiered screening strategy (title, abstract and full content screen) were used. Guidelines were eligible for inclusion if they, a) were published between 2000 and 2015 in English or French, and b) provided guidance on HIV screening/testing intervals for at least one population.

Results: Of the 609 documents retrieved from the search, 34 guidelines met the eligibility criteria. The most frequently mentioned populations were pregnant women, men who have sex with men (MSM) and the general population. Overall, there was consensus on at least annual testing for MSM, intravenous drug users, individuals with HIV-positive sex partners, individuals with multiple partners, sex workers and their clients, migrants from HIV-endemic countries and indigenous peoples. Of the 20 guidelines that provided recommendations for pregnant women, the most common recommendation $(n=9)$ was to test as early as possible during each pregnancy; four guidelines recommended screening during the first prenatal visit; three recommended routine HIV testing; and four suggested retesting in the third trimester regardless of maternal risk of HIV infection. Consensus on HIV testing of the general public, incarcerated people and individuals diagnosed with other sexually transmitted infections (STIs) was lacking. Four guidelines cited a lack of data for not providing specific recommendations in the general population.

Conclusions: Additional evidence is needed to refine the recommendations for pregnant women and inform the optimal timing of HIV testing, especially in the general population, individuals diagnosed with other STIs and incarcerated people.

\section{Affiliation}

${ }^{1}$ Centre for Communicable Diseases and Infection Control, Public Health Agency of Canada, Ottawa, ON

*Correspondence: karen. timmerman@phac-aspc.gc.ca

Suggested citation: Austin T, Traversy GP, Ha S, Timmerman K. Canadian and international recommendations on the frequency of HIV screening and testing: A systematic review. Can Comm Dis Rep 2016;42:161-8.

https://doi.org/10.14745/ccdr.v42i08a03

\section{Introduction}

Diagnosed and treated human immunodeficiency virus (HIV) infection is considered a chronic disease (1). Early detection and treatment of HIV is important not only for the individuals who are infected but also to prevent transmission of the virus (2). Clinical trials have shown that early initiation of HIV treatment reduces viral load, thereby decreasing infectivity and potentially preventing HIV transmission $(3,4)$.
Low rates of screening and testing have been identified as a potential limiting factor in the success of HIV-prevention strategies $(5,6)$. Approximately $30-50 \%$ of new infections are a result of individuals who are unaware of their infection $(7,8)$. Research among men who have sex with men (MSM), injection drug users (IDUs) and heterosexual men and women indicates that once individuals learn of their HIV-positive status they are more likely to take steps to minimize the likelihood of transmission (9). However, it was estimated that at the end 
of 2014 , about $21 \%$ of people living with HIV in Canada were unaware of their infection (10).

The Public Health Agency of Canada (PHAC)'s HIV Screening and Testing Guide recommends HIV screening as part of routine care and annual testing for individuals involved in high-risk practices (2). In addition to MSM and IDU, other commonly identified risk groups for HIV infection include individuals with HIV-positive sex partners and individuals with multiple or anonymous partners $(2,11-15)$.

However, the benefits and frequency of HIV testing must be weighed against costs, and there is a lack of clarity as to the ideal frequency of testing in other populations.

The objective of this systematic review was to address the question: What are the recommended intervals for HIV screening and testing among various population groups in Canada and elsewhere?

\section{Methods}

\section{Search strategy}

A research librarian-designed comprehensive search of electronic databases identified guidelines published in peer-reviewed journals. Government and non-governmental organization (NGO) websites were also searched to identify any guidelines that may have been posted but not published in the scientific literature. The electronic databases searched included MEDLINE, Embase, Scopus, Cochrane Library and the Canadian Electronic Library (CEL). See Appendix 1 for a complete list of the government and NGO websites searched.

The search terms were the same for both types of searches: "HIV testing frequency," "HIV testing interval," "HIV guideline," "HIV testing guideline," "HIV screening," "HIV screening frequency," "HIV screening guideline," "HIV screening and testing guideline," "HIV screening and testing recommendations," "HIV screening recommendations," "HIV testing recommendations," "STI guidelines," "STI testing intervals" and "STI testing frequency." Search strings for the different databases are identified in Appendix 2.

Inclusion and exclusion criteria are listed in Table 1. The search was restricted to guidelines published or posted within the last 15 years to capture the influence of new HIV prevention methods (e.g., treatment as prevention [TasP]).

\section{Guideline selection}

We conducted a three-tiered screening process: title screen, abstract screen and full content screen. Three authors (TA, GT and $\mathrm{SH}$ ) independently screened the titles. Titles with the
Table 1: Inclusion and exclusion criteria

\begin{tabular}{|c|c|c|}
\hline Item & Inclusion criteria & Exclusion criteria \\
\hline $\begin{array}{l}\text { Nature of } \\
\text { recommendation }\end{array}$ & $\begin{array}{l}\text { Provides position, } \\
\text { recommendations or } \\
\text { guidance on HIV testing } \\
\text { intervals or frequency of } \\
\text { testing (all populations } \\
\text { and subgroups) } \\
\text { Multiple } \\
\text { recommendations } \\
\text { published from the } \\
\text { same organization (e.g., } \\
\text { updates or addendums) }\end{array}$ & $\begin{array}{l}\text { No mention of testing } \\
\text { intervals or frequency of } \\
\text { HIV testing } \\
\text { Recommendations } \\
\text { related to individuals } \\
\text { who already have } \\
\text { HIV (e.g., TB/HIV } \\
\text { co-infection or HIV } \\
\text { treatment/management) }\end{array}$ \\
\hline $\begin{array}{l}\text { Language of } \\
\text { publication }\end{array}$ & English, French & $\begin{array}{l}\text { Languages other than } \\
\text { English and French }\end{array}$ \\
\hline $\begin{array}{l}\text { Date of } \\
\text { publication }\end{array}$ & $\begin{array}{l}\text { Recommendations } \\
\text { published from January } \\
2000 \text { to August } 2015\end{array}$ & $\begin{array}{l}\text { Guidelines published } \\
\text { prior to January } 2000\end{array}$ \\
\hline
\end{tabular}

Abbreviations: HIV, human immunodeficiency virus; TB, tuberculosis

terms "guideline," "strategy," "directive," "recommendation," "guidance" or "position" were included. Guidelines on HIV treatment or the management of opportunistic infections and co-infected populations were excluded. Two authors (TA, GT) independently screened the abstracts and excluded those that did not refer to HIV screening and testing. Disagreements between reviewers at either stage were resolved through discussion with a third reviewer (KT) and a fourth, if required. Two authors (TA, GT) then completed the full content screen. Guidelines that did not provide specific information on the recommended frequency or intervals of HIV screening and testing for any population group were excluded. Only primary source guidelines were included. Guidelines were considered duplicates if the same recommendation was published in multiple locations or if an article summarized or endorsed a guideline.

\section{Data extraction}

Data were extracted on the country of publication, population screened and testing frequency. Guidelines were categorized as Canadian, foreign, or international (spanning multiple countries, such as those from the World Health Organization). The population groups initially targeted in this review were the general population, MSM and IDU, but other population groups were also noted.

\section{Results}

A total of 609 documents were retrieved from the search. After duplicates were removed and inclusion/exclusion criteria applied, the final review included 34 guidelines (Figure 1). 
Figure 1: Screening methodology and final results flow chart

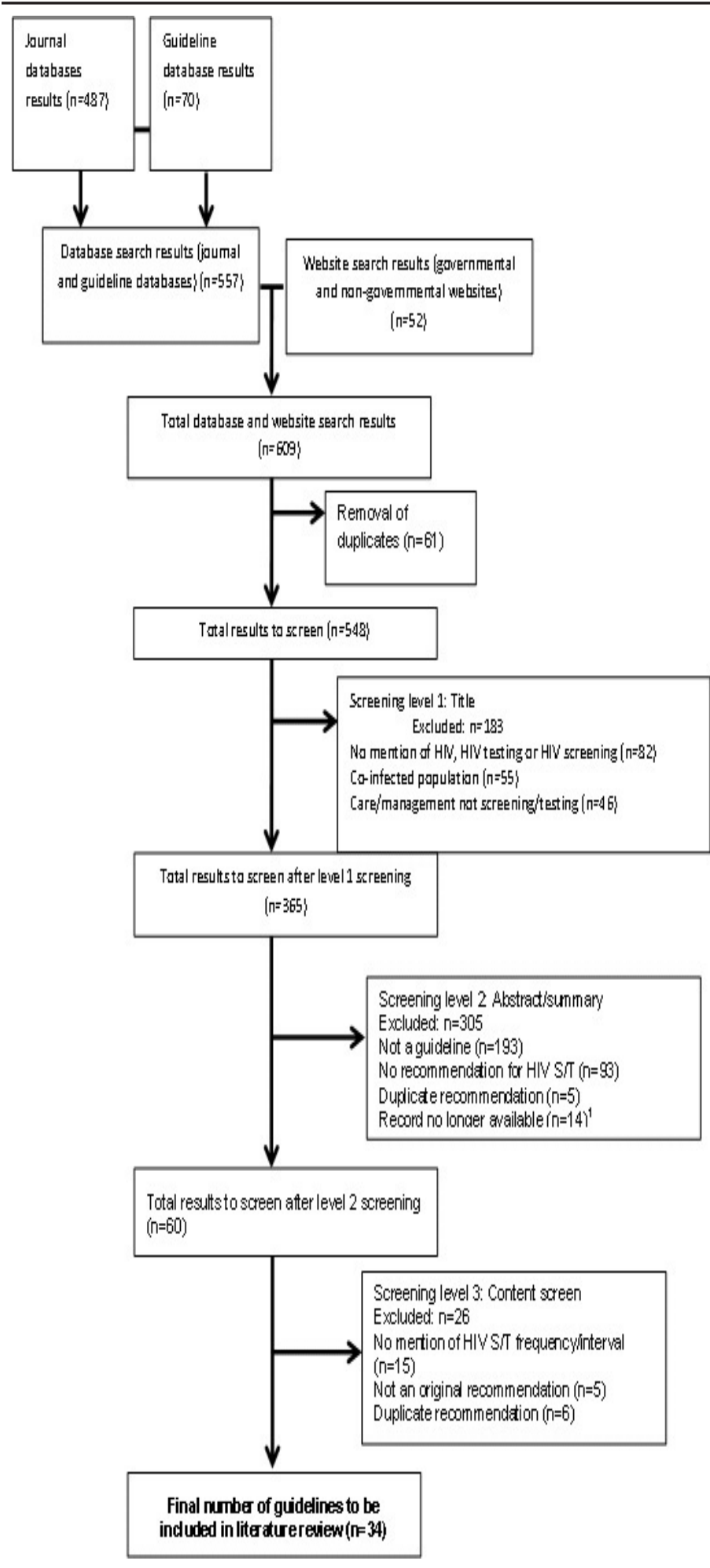

Abbreviations: HIV, human immunodeficiency virus; S/T, screening/testing

${ }^{1}$ Refers to documents for which abstracts were identified but full texts were either unavailable or inaccessible
The characteristics of included guidelines are summarized in Table 2. Two-thirds (65\%) came from the United States and Europe. In addition to the general population, MSM and IDU, several other key populations emerged: pregnant women, migrants from HIV-endemic regions, indigenous peoples, adolescents, incarcerated individuals, partners of unknown HIV status and others.

Table 2: Overview of 34 guidelines on the frequency of HIV testing by geographic region and key populations groups

\begin{tabular}{|c|c|c|}
\hline Type & Characteristic & Number (\%) \\
\hline \multirow{7}{*}{$\begin{array}{l}\text { Geographic } \\
\text { region }\end{array}$} & United States & $12(35)$ \\
\hline & Europe & $10(29)$ \\
\hline & Canada & $5(15)$ \\
\hline & Africa & $2(6)$ \\
\hline & Australia & $2(6)$ \\
\hline & $\begin{array}{l}\text { World Health } \\
\text { Organization }\end{array}$ & $2(6)$ \\
\hline & Asia & $1(3)$ \\
\hline \multirow{14}{*}{$\begin{array}{l}\text { Key } \\
\text { populations } \\
\text { mentioned }\end{array}$} & Pregnant & 20 (59) \\
\hline & MSM & $19(56)$ \\
\hline & General population & $14(41)$ \\
\hline & IDU & $13(38)$ \\
\hline & Multiple partners & $7(21)$ \\
\hline & HIV-positive sex partner & $7(21)$ \\
\hline & Other STI diagnosis & $5(15)$ \\
\hline & $\begin{array}{l}\text { Sex workers and their } \\
\text { clients }\end{array}$ & $4(12)$ \\
\hline & $\begin{array}{l}\text { Migrants from } \\
\text { HIV-endemic countries }\end{array}$ & $4(12)$ \\
\hline & Indigenous peoples & $3(9)$ \\
\hline & Adolescents & $3(9)$ \\
\hline & Incarcerated individuals & $3(9)$ \\
\hline & $\begin{array}{l}\text { Transgender men and } \\
\text { women }\end{array}$ & $2(6)$ \\
\hline & $\begin{array}{l}\text { Partner with unknown HIV } \\
\text { status }\end{array}$ & $2(6)$ \\
\hline
\end{tabular}

All 34 Canadian, foreign and international guideline $s$ are summarized in Table 3. Of these, 9 provided recommendations only for high-risk groups and the remaining 25 provided recommendations for other risk groups (e.g., pregnant women and the general population). Five guidelines were updates to previous guidelines. 


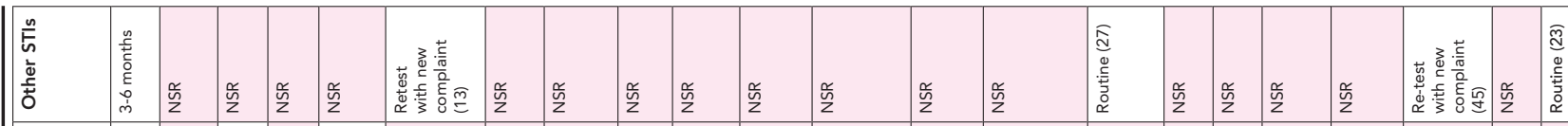

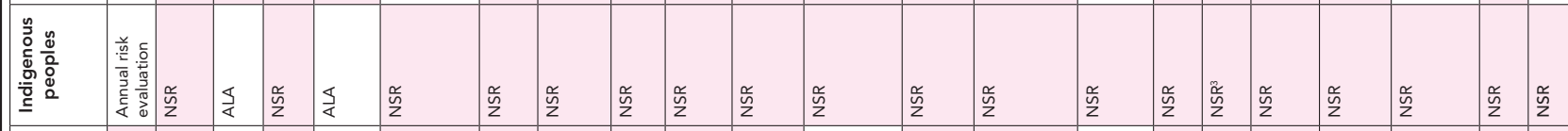
Eng

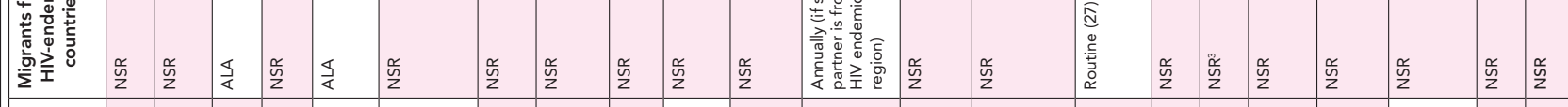

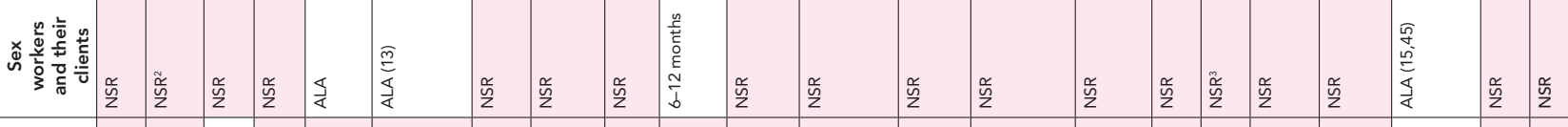

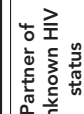


More recent guidelines have focused on routine testing (i.e., not recommending a specific testing interval but rather providing a recommendation to test everyone) with more frequent testing for individuals who engage in high-risk behaviours $(2,16-18)$.

The most frequently mentioned populations were pregnant women, MSM and the general population. Of all 20 guidelines that provided recommendations for pregnant women, the most common recommendation $(n=9)$ was to test as early as possible during each pregnancy; 4 guidelines recommended screening during the first prenatal visit $(2,19-21) ; 3$ recommended routine HIV testing $(16,22,23)$; and 4 suggested retesting in the third trimester regardless of maternal risk of HIV infection $(13,17,24,25)$.

Of the 19 guidelines that considered MSM, 14 provided a specific testing frequency, 3 recommended routine testing without specific testing intervals $(23,26,27)$ and 2 cited insufficient evidence to determine a testing interval but recommended that MSM be screened more frequently $(2,18)$. Altogether 14 recommended testing at least annually.

Testing at least annually was also the most common recommendation for IDU (11 of 13 guidelines), individuals with HIV-positive sex partners (6 of 7), individuals with multiple partners (4 of 7), sex workers and their clients (4 of 4), migrants from HIV-endemic countries (3 of 4) and indigenous peoples (2 of 3). Overall, the recommendations for frequency of testing higher-risk populations varied little.

Recommendations for the general population varied slightly. Some (2 of 14) focused on a specific time, whereas the majority (8 of 14) focused on routine or normalized testing without providing a specific interval (e.g., PHAC, European Union, Central African Republic). Four guidelines cited a lack of data as reason for not providing specific recommendations in the general population $(16,28-30)$.

The guidelines differ regarding whether sufficient evidence exists to formulate testing frequency recommendations in certain populations $(2,18,28,29)$. This is the case for both populations in which there is consistency across guideline recommendations (e.g., MSM and IDU), and for populations in which there was some consistency or no guideline (e.g., incarcerated people).

Guidelines for people diagnosed with STIs commonly recommend routine HIV testing $(n=3)$ or re-testing with each new STI diagnosis $(n=2)$. The emergence of this population in this review highlights STI diagnoses as a potential proxy for high-risk sexual behaviour and identifying individuals at higher risk for HIV infection.

The least frequently mentioned populations included incarcerated individuals, adolescents, individuals with partners of unknown HIV status, and transgender men and women.

\section{Discussion}

This review identified 34 guidelines on the frequency of HIV testing. In addition to testing frequency recommendations for high-risk groups, several guidelines also included recommendations for the general population and pregnant women, highlighting a shift from risk-based and targeted-testing $(13,24,33,46)$ to incorporating HIV testing into routine care $(2,13,16,18,21,32,39)$. There was good consensus that testing at least annually is recommended in higher-risk populations.

Most guidelines suggest testing early in pregnancy, and some recommend testing again in the third trimester. There is a lack of consensus on some subgroups (i.e., incarcerated individuals, the general population and individuals diagnosed with other STIs), and there appears to be insufficient evidence to make recommendations for the general population and incarcerated people. Differences in the recommendations for population groups may be a result of the varying types of evidence used to inform the guidelines.

Several factors should be considered when interpreting these results. The strengths of this review include a thorough search strategy, and consistent, objective assessment and data extraction of the studies. There are also a number of limitations. Guidelines that may have been published in languages other than French and English were not included in this review. Of note, there were few published guidelines from Asia and Africa. Since these regions have high HIV incidence and prevalence rates, guidelines from these regions were either not captured by our search parameters or there is a lack of guidance on the optimal intervals for HIV screening and testing in these regions.

Research is needed to examine and critically appraise the evidence for the frequency of HIV testing recommendations in various populations. Specific research could be aimed at identifying the optimal testing interval for the general population, for adolescents, for transgender men and women and for incarcerated people $(47,48)$ as well as the optimal frequency of testing for indigenous peoples, ethnocultural communities with high incidences of HIV and domestic migrant workers.

In summary, HIV screening and testing is an extremely important tool within the continuum of HIV care. Although many guidelines have been developed to identify the ideal frequency of testing for different populations, there are inconsistencies among them and the evidence base for some populations appear to be lacking. Additional evidence to inform the optimal frequency of HIV screening and testing in different populations could strengthen the global efforts to eradicate this disease.

\section{Acknowledgements}

We would like to thank Jun Wu and Margaret Gale-Rowe for their constructive feedback on the manuscript. We would also like to thank Ella Westhaver, the research librarian who helped us design and carry out our systematic guideline search, and Jessica Yau for her contributions to the revision of this manuscript.

\section{Conflict of interest}

None. 


\section{Funding}

This study was supported by the Public Health Agency of Canada. The authors have no additional sources of external funding to declare.

\section{Appendix 1: Websites searched}

The website search was divided into national and international sites and government and non-governmental/stakeholder sites.

\begin{tabular}{|c|c|}
\hline Type of website & Organization \\
\hline $\begin{array}{l}\text { National } \\
\text { governmental }\end{array}$ & $\begin{array}{l}\text { Public Health Agency of Canada } \\
\text { Health Canada } \\
\text { All Canadian provincial and territorial health } \\
\text { departments }\end{array}$ \\
\hline $\begin{array}{l}\text { International } \\
\text { governmental }\end{array}$ & $\begin{array}{l}\text { United States Centers for Disease Control and } \\
\text { Prevention (CDC) } \\
\text { European Centre for Disease Prevention and Control } \\
\text { (ECDC) } \\
\text { National Institutes of Health (NIH) } \\
\text { National Institute for Health and Care Excellence (NICE) } \\
\text { Haute autorité de santé (HAS)/French National } \\
\text { Authority for Health } \\
\text { United Kingdom Department of Health } \\
\text { Australian Department of Health } \\
\text { New Zealand Ministry of Health } \\
\text { Scottish Intercollegiate Guidelines Network (SIGN) } \\
\text { Royal Australian College of General Practitioners } \\
\text { (RACGP) } \\
\text { Australasian Society for HIV Medicine (ASHM) } \\
\text { British Association for Sexual Health and HIV (BASHH) }\end{array}$ \\
\hline $\begin{array}{l}\text { National } \\
\text { non-governmental / } \\
\text { stakeholder }\end{array}$ & $\begin{array}{l}\text { Canadian Medical Association } \\
\text { Canadian AIDS Treatment Information Exchange (CATIE) } \\
\text { Canadian Task Force on Preventive Health Care } \\
\text { (CTFPHC) } \\
\text { Canadian AIDS Society (CAS) } \\
\text { Association of Medical Microbiology and Infectious } \\
\text { Disease Canada (AMMI Canada) } \\
\text { Canadian Nurses Association (CNA) } \\
\text { College of Family Physicians of Canada (CFPC) } \\
\text { British Colombia Centre for Excellence in HIV/AIDS } \\
\text { Canadian Treatment Action Council (CTAC) } \\
\text { Canadian Association of Nurses in HIV/AIDS Care } \\
\text { (CANAC) } \\
\text { Registered Nurses' Association of Ontario (RNAO) }\end{array}$ \\
\hline $\begin{array}{l}\text { International } \\
\text { non-governmental / } \\
\text { stakeholder }\end{array}$ & $\begin{array}{l}\text { Joint United Nations Programme on HIV/AIDS } \\
\text { (UNAIDS) } \\
\text { World Health Organization (WHO) (accessed } \\
\text { recommendations from Asia and Africa) } \\
\text { British HIV Association (BHIVA) } \\
\text { European Monitoring Centre for Drugs and Drug } \\
\text { Addiction (EMCDDA) } \\
\text { United States Preventive Services Task Force (USPSTF) } \\
\text { International AIDS Society (IAS) } \\
\text { International Association of Providers of AIDS Care } \\
\text { (IAPAC) } \\
\text { Infectious Diseases Society of America (IDSA) } \\
\text { Global Fund to Fight AIDS, Tuberculosis and Malaria } \\
\text { (GFATM) } \\
\text { European AIDS Clinical Society (EACS) }\end{array}$ \\
\hline
\end{tabular}

Appendix 2: Database search strings

\section{MEDLINE search string}

Database(s): Ovid MEDLINE(R) In-Process \& Other Non-Indexed Citations, Ovid MEDLINE(R) Daily, Ovid MEDLINE(R) and Ovid OLDMEDLINE(R) 1946 to Present

\begin{tabular}{|c|c|c|}
\hline No. & Searches & Results \\
\hline 1 & $\begin{array}{l}\text { (hiv or human immunodeficiency or human immune } \\
\text { deficiency or vih).ti. }\end{array}$ & 188944 \\
\hline 2 & $\begin{array}{l}\text { exp *HIV Infections/ or exp *HIV/ or exp HIV } \\
\text { Infections/ep }\end{array}$ & 246368 \\
\hline 3 & (hiv positive* or hiv+ or vih positi* or vih+).ti. & 161297 \\
\hline 4 & 1 or 2 or 3 & 272101 \\
\hline 5 & exp Mass Screening/ & 106834 \\
\hline 6 & $\begin{array}{l}\text { (frequency or schedule or interval?).mp. [mp=title, } \\
\text { abstract, original title, name of substance word, } \\
\text { subject heading word, keyword heading word, } \\
\text { protocol supplementary concept word, rare disease } \\
\text { supplementary concept word, unique identifier] }\end{array}$ & 1348682 \\
\hline 7 & $\begin{array}{l}\text { (guideline? or recommendation? or policy).mp. } \\
\text { [mp=title, abstract, original title, name of substance } \\
\text { word, subject heading word, keyword heading } \\
\text { word, protocol supplementary concept word, rare } \\
\text { disease supplementary concept word, unique } \\
\text { identifier] }\end{array}$ & 614880 \\
\hline 8 & $\begin{array}{l}\text { [(Testing or screening) adj5 (frequency or interval or } \\
\text { guideline? or recommendation?)].ti,hw. }\end{array}$ & 2834 \\
\hline 9 & 4 and 7 and 8 & 178 \\
\hline 10 & 4 and 5 and 6 and 7 & 94 \\
\hline 11 & 9 or 10 & 265 \\
\hline 12 & 10 not 9 & 87 \\
\hline 13 & $\begin{array}{l}\text { [(Testing or screening) adj6 (frequency or interval or } \\
\text { guideline? or recommendation?)].ti,hw. }\end{array}$ & 4611 \\
\hline 14 & 4 and 7 and 13 & 238 \\
\hline 15 & 14 not 9 & 60 \\
\hline 16 & $\begin{array}{l}\text { limit } 14 \text { to (yr="2000 -Current" and (english or } \\
\text { french) }\end{array}$ & 182 \\
\hline
\end{tabular}

\section{Scopus search string}

Scopus OECD ( TITLE ( hiv OR aids OR vih ) AND ( TITLE-ABSKEY ( hiv OR aids OR vih ) W/6 (testing OR screening ) W/6 ( frequency OR interval* OR guidelin* OR recommendation ) ) ) AND TITLE-ABS-KEY ( guidelin* OR recommendation*) PUBYEAR > 2000 ) AND ( TITLE-ABS-KEY ( spain OR slovakia OR poland OR portugal OR greece OR germany OR france OR finland OR denmark OR "Czech Republic" OR canad* OR belgium OR austria OR australia OR norway OR "New Zealand" OR netherlands OR mexico OR luxembourg OR korea OR japan OR italy OR iceland OR hungary OR ireland OR "United States" OR great-britain OR "United Kingdom" OR turkey OR switzerland OR sweden ) ) AND ( LIMIT-TO ( LANGUAGE , "English" ) OR LIMIT-TO ( LANGUAGE , "French" ) ) 284 


\section{Embase search string}

Database(s): Embase 1974 to 2015 September 21

\begin{tabular}{|c|c|c|}
\hline No. & Searches & Results \\
\hline 1 & $\begin{array}{l}\text { (Spain or Slovakia or Poland or Portugal or Greece } \\
\text { or Germany or France or Finland or Denmark or } \\
\text { Czech-Republic or Canada or Belgium or Austria or } \\
\text { Australia or Norway or New-Zealand or Netherlands } \\
\text { or Mexico or Luxembourg or Korea or Japan or Italy } \\
\text { or Iceland or Hungary or Ireland or United-States or } \\
\text { Great-Britain or Turkey or Switzerland or Sweden). } \\
\text { mp. }\end{array}$ & 3697234 \\
\hline 2 & $\begin{array}{l}\text { (hiv or human immunodeficiency or human immune } \\
\text { deficiency or vih).ti. }\end{array}$ & 213771 \\
\hline 3 & exp *Human immunodeficiency virus/ & 75032 \\
\hline 4 & Human immunodeficiency virus infection/ep & 32614 \\
\hline 5 & *Human immunodeficiency virus infection/ & 154397 \\
\hline 6 & 2 or 3 or 4 or 5 & 258779 \\
\hline 7 & exp mass screening/ & 174825 \\
\hline 8 & (frequency or schedule or interval?).mp. & 1558540 \\
\hline 9 & (guideline? or recommendation? or policy).mp. & 917993 \\
\hline 10 & 6 and 7 and 8 and 9 & 62 \\
\hline 11 & $\begin{array}{l}\text { [(Testing or screening) adj6 (frequency or interval or } \\
\text { guideline? or recommendation?)].ti,hw. }\end{array}$ & 6001 \\
\hline 12 & 6 and 9 and 11 & 313 \\
\hline 13 & 1 and 12 & 123 \\
\hline 14 & 12 not 13 & 190 \\
\hline 15 & $\begin{array}{l}\text { limit } 12 \text { to [(english or french) and } y r=" 2000 \\
\text {-Current")] }\end{array}$ & 245 \\
\hline
\end{tabular}

Abbreviation: No., Number

\section{Cochrane library search string}

"hiv".ti and "interval".ti and "guideline".ti and

"recommendation".ti Publicaton Year from 2000 to 2015 (Word variation have been searched)

\section{Canadian electronic library search string}

Canadian Electronic Library: Canadian Publishers Collection, Canadian Public Policy Collection, Canadian Health Research Collection

Title: HIV AND all:screening OR Testing

\section{References}

1. Public Health Agency of Canada. What is HIV/AIDS? Ottawa (ON); The Agency; 2008. http://www.phac-aspc.gc.ca/aids-sida/ info/index-eng.php.

2. Public Health Agency of Canada. Human immunodeficiency virus: HIV screening and testing guide. Ottawa (ON); The Agency; 2012. http://www.phac-aspc.gc.ca/aids-sida/guide/ hivstg-vihgdd-eng.php.
3. Lundgren JD, Babiker AG, Gordin F, Emery S, Grund B, Sharma $S$ et al.; INSIGHT START Study Group. Initiation of antiretroviral therapy in early asymptomatic HIV infection. N Engl J Med 2015;373:795-807.

4. Cohen MS, Chen YQ, McCauley M, Gamble T, Hosseinipour MC, Kumarasamy N, et al. Prevention of HIV-1 Infection with Early Antiretroviral Therapy. N Engl J Med 2011;365:493-505.

5. McNairy ML, Cohen M, El-Sadr WM. Antiretroviral therapy for prevention is a combination strategy. Curr HIV/AIDS Rep 2013;10:152-8.

6. McNairy ML, El-Sadr WM. Antiretroviral therapy for the prevention of HIV transmission: what will it take? Clin Infect Dis 2014;58:1003-11.

7. Marks G, Crepaz N, Janssen RS. Estimating sexual transmission of HIV from persons aware and unaware that they are infected with the virus in the USA. AIDS 2006;20:1447-50.

8. Skarbinski J, Rosenberg E, Paz-Bailey G, Hall HI, Rose CE, Viall $\mathrm{AH}$, et al. Human immunodeficiency virus transmission at each step of the care continuum in the United States. JAMA Intern Med 2015;175:588-96.

9. Marks G, Crepaz N, Senterfitt JW, Janssen RS. Meta-analysis of high-risk sexual behavior in persons aware and unaware they are infected with HIV in the United States: implications for HIV prevention programs. J Acquir Immune Defic Syndr 2005;39:446-53.

10. Tomas K, Dhami P, Houston C, Ogunnaike-Cook S, Rank C. HIV in Canada: 2009 to 2014. Can Comm Dis Rep 2015;41:292. http://www.phac-aspc.gc.ca/publicat/ccdr-rmtc/15vol41/drrm41-12/ar-02-eng.php.

11. AIDS.gov. Who is at Risk for HIV? Washington (DC): HHS; 2014. https://www.aids.gov/hiv-aids-basics/prevention/reduce-yourrisk/who-is-at-risk-for-hiv/.

12. Public Health Agency of Canada. Summary: Estimates of HIV incidence, prevalence and proportion undiagnosed in Canada, 2014. Ottawa (ON): The Agency; 2015. http://healthycanadians. gc.ca/publications/diseases-conditions-maladies-affections/hivaids-estimates-2014-vih-sida-estimations/index-eng.php\#t1.

13. Branson BM, Handsfield HH, Lampe MA, Janssen RS, Taylor AW, Lyss SB, et al. Revised recommendations for HIV testing of adults, adolescents, and pregnant women in health-care settings. MMWR Recomm Rep 2006;55:1-17.

14. European Monitoring Centre for Drugs and Drug Addiction. Guidelines for testing HIV, viral hepatitis and other infections in injecting drug users. Lisbon (PT): EMCDDA; 2010.

15. World Health Organization. Guidance on testing and counselling for HIV in settings attended by people who inject drugs: Improving access to treatment, care and prevention. Geneva (CH): WHO; 2009.

16. Gokengin D, Geretti AM, Begovac J, Palfreeman A, Stevanovic M, Tarasenko O, et al. 2014 European guideline on HIV testing. Int J STD AIDS 2014;25:695-704.

17. Workowski KA, Bolan GA; Centers for Disease Control and Prevention. Sexually transmitted diseases treatment guidelines, 2015. MMWR 2015;64(RR-03):1-137.

18. U.S. Preventive services task force. Screening for HIV: recommendation statement. Am Fam Phys 2014;89:666A-D. 
19. Sous-comité Optimiser le dépistage du VIH, Comité sur les infections transmissibles sexuellement et par le sang (ITSS). Optimiser le dépistage et le diagnostic de l'infection par le virus de l'immunodéficience humaine. Québec: Gouvernement du Québec; 2011. (Available in French only: https://www.inspq.qc.ca/pdf/publications/1324_ OptimiserDepistageDiagnosticlnfectionVIH.pdf).

20. Office of the Provincial Health Officer of British Columbia. HIV testing guidelines for the province of British Columbia 2014. Victoria (BC): The Office of the Provincial Health Officer of British Columbia; 2014.

21. British HIV Association, British Association of Sexual Health and HIV, British Infection Society. UK national guidelines for HIV testing 2008. London (UK): The Association; 2008.

22. Saskatchewan HIV Provincial Leadership Team. Saskatchewan HIV testing policy. Regina (SK): The Team; 2013.

23. Delpech V, Nardone A, Thornton A, Kall M; Medical Foundation for AIDS \& Sexual Health. ECDC guidance: HIV testing: increasing uptake and effectiveness in the European Union Evidence synthesis for guidance on HIV testing. Stockholm (SE); ECDC; 2010.

24. Centers for Disease Control and, Prevention. Revised recommendations for HIV screening of pregnant women. MMWR Recomm Rep 2001;50:63-85.

25. Workowski KA, Berman S; Centers for Disease Control and Prevention (CDC). Sexually transmitted diseases treatment guidelines, 2010. MMWR Recomm Rep 2010;59:1-110.

26. European Centre for Disease Prevention and Control. HIV and STI prevention among men who have sex with men. Stockholm (SE): ECDC; 2015.

27. National Institute for Health and Care Excellence. HIV testing: increasing uptake in black Africans. London (UK): NICE; 2011.

28. Islamic Republic of Afghanistan, Ministry of Public Health. National HIV Testing and Counseling Guideline. Kabul (AF); 2008. http://www.who.int/hiv/pub/guidelines/afghanistan_art. pdf.

29. Haute Autorité de Santé. Dépistage de lìnfection par le VIH en France: stratégies et dispositif de dépistage. Saint-Denis La Plaine Cedex (FR): HAS; 2009.(Available in French only: http:// social-sante.gouv.fr/IMG/pdf/argumentaire_depistage_vih_ HAS_2009-2.pdf).

30. Poljak M, Smit E, Ross J. 2008 European guideline on HIV testing. Int J STD AIDS 2009;20(2):77-83.

31. Centers for Disease Control and Prevention; Workowski KA, Berman SM. Sexually transmitted diseases treatment guidelines, 2006. MMWR 2006; 55(RR-11):1-94.

32. AIDS Bureau, Ministry of Health and Long-Term Care. Ontario HIV testing frequency guidelines: guidance for counselors and health professionals. Toronto (ON): The Ministry; 2012 Apr.

33. Anderson T. Revised Guidelines for HIV Counseling, Testing, and Referral. MMWR 2001; 50:1-86.

34. Beckwith C, Bick J, Clow W, Courtenay-Quirk C, Ellington R, Flanigan $T$, et al. HIV testing implementation guidance for correctional settings; Atlanta (GA): Centers for Disease Control and Prevention (CDC); 2009. http://www.cdc.gov/hiv/pdf/risk_ correctional_settings_guidelines.pdf.
35. Control Program and the HIV/AIDS Control Program, Public Health-Seattle and King County. Sexually transmitted disease and HIV screening guidelines for men who have sex with men. Sex Transm Dis 2001;28:457-9.

36. Sexually transmitted infections: UK national screening and testing guidelines; 2006. Macclesfield (UK): British Association of Sexual Health and HIV; 2006.

37. Integrated guidelines for prevention, testing, care and treatment of HIV/AIDS in Liberia. Greater Monrovia (LR): Ministry of Health and Social Welfare, Republic of Liberia; 2007.

38. Qaseem A, Snow V, Shekelle P, Hopkins Jr. R, Owens DK. Screening for HIV in health care settings: a guidance statement from the American College of Physicians and HIV Medicine Association. Ann Intern Med 2009;150:125-31.

39. Guide du dépistage et conseil du VIH à l'initiative du prestataire. Greater Monrovia (LR): Ministère de la Santé Publique, de la Population et de la Lutte Contre le Sida; 2010.

40. STIs in Gay Men Action Group. Australian sexually transmitted infection \& HIV testing guidelines 2014 for asymptomatic men who have sex with men; 2014. Sydney (AU): ASHM; 2014. http://stipu.nsw.gov.au/wp-content/uploads/STIGMA_Testing_ Guidelines_Final_v5.pdf.

41. STIs in Gay Men Action Group. Sexually transmitted infection testing guidelines for men who have sex with men 2010; Sydney (AU): ASHM; 2010. http://stipu.nsw.gov.au/wp-content/ uploads/163932_STI_testing_guidelines_for_MSM_2010.pdf.

42. National Institute for Health and Care Excellence. Increasing the uptake of HIV testing to reduce undiagnosed infection and prevent transmission among men who have sex with men. London (UK): NICE; 2011.

43. New York State Department of Health. HIV testing during pregnancy and at delivery. New York (NY); Department of Health; 2011.

44. Committee opinion no: 635: Prenatal and perinatal human immunodeficiency virus testing: Expanded recommendations. Obstet Gynecol 2015;125:1544-7.

45. World Health Organization. Delivering HIV test results and messages for re-testing and counselling in adults. Geneva $(\mathrm{CH})$ : WHO; 2010. http://www.who.int/hiv/pub/vct/hiv_re_testing/en/.

46. Beckwith CG, Flanigan TP, del Rio C, Simmons E, Wing EJ, Carpenter CC, et al. It is time to implement routine, not riskbased, HIV testing. Clin Infect Dis 2005;40:1037-40.

47. Clements-Noelle K, Marx R, Guzman R, Katz M. HIV prevalence, risk behaviors, health care use, and mental health status of transgender persons: implications for public health intervention. Am J Public Health 2001;91:915-21.

48. Huang ZJ, He N, Nehl EJ, Zheng T, Smith BD, Zhang J, et al. Social network and other correlates of HIV testing: findings from male sex workers and other MSM in Shanghai, China. AIDS Behav 2012;16:858-71. 